Masood R., Gonzalez V., and Lim J. (2017). "Value Stream Mapping - A Case Study of Cold-Formed Steel House Framing for Offsite Manufacturing Supply Chain.” In: LC3 2017 Volume II - Proceedings of the 25th Annual Conference of the International Group for Lean Construction (IGLC), Walsh, K., Sacks, R., Brilakis, I. (eds.), Heraklion, Greece, pp. 829-836. DOI: https://doi.org/10.24928/2017/0071

\title{
VALUE STREAM MAPPING - A CASE STUDY OF COLD-FORMED STEEL HOUSE FRAMING FOR OFFSITE MANUFACTURING SUPPLY CHAIN
}

\author{
Rehan Masood ${ }^{1}$, Vicente Gonzalez ${ }^{2}$, and James B.P. Lim $^{3}$
}

\begin{abstract}
Offsite manufacturing (OSM) has the potential to help reduce the housing shortfall by increasing the supply of housing stock. The poor performance of the construction supply chain is the main reason for the low uptake of OSM. OSM supply chain characteristics such as configuration, information flow and material flow are different for OSM technologies. Furthermore, there are inefficiencies in the supply chain causing waste, which also varies with OSM technology. A case study of the OSM supply chain for structural framing for cold-formed steel (CFS) houses is mapped and assessed using value stream mapping (VSM). From the VSM it is possible to understand current performance and determine opportunities for improvement. Such information can help foster further adoption of OSM of CFS in housing.
\end{abstract}

Keywords: Offsite manufacturing, Supply chain management, Value stream mapping, Housing, Cold-formed steel framing

\section{INTRODUCTION}

The poor performance of housing industry (London \& Siva, 2011), has resulted in a shortfall of the housing building stock globally, with New Zealand not being an exception (Bassett \& Malpass, 2015). Offsite manufacturing (OSM) (otherwise known as prefabrication) has the potential to enhance production for housing with cost effective solutions, from prefabricated components to complete building (Goulding et al. 2015).

However, OSM has shown slow adoption globally (MHC, 2011) as well as in New Zealand (Scofield et al. 2009). The poor performance of OSM supply chain management (SCM) is one of the reasons for its low uptake in the housing industry (Pan et al. 2012). Also, application of SCM concepts is a large challenge for key stakeholders (Goulding et al. 2015) due to its dependency on technological development (Edum-Fotwe et al. 2001). CFS as emerging OSM technology, however, does have the main potential to reduce the lead time of house building supply chain (SC) (Donyavi et al., 2009). There is difference in configurations, information flow, material flow and problems of SCM.

This is a preliminary study on the performance of OSM SCM that focusses on CFS house framing using value stream mapping (i.e. following the design-to-order strategy). The key processes are mapped and also the identification of waste types in the value stream. This study can lead to an improved performance of the CFS house framing SCM.

PhD Candidate, Department of Civil and Environmental Engineering, The University of Auckland, Auckland, New Zealand, rmas769@aucklanduni.ac.nz

2 Senior Lecturer, Department of Civil and Environmental Engineering, The University of Auckland, Auckland, New Zealand, v.gonzalez@auckland.ac.nz

3 Senior Lecturer, Department of Civil and Environmental Engineering, The University of Auckland, Auckland, New Zealand, james.lim@auckland.ac.nz 
Value Stream Mapping - A Case Study of Cold-Formed Steel House Framing for Offsite Manufacturing Supply Chain

\section{LITERATURE REVIEW}

The concept of SCM is not well utilized in both practice and research, even though it has the potential to improve the speed and quality of house building projects (London \& Siva, 2011), specifically for industrial house building projects (using OSM technologies) (Gann, 1996). OSM SCM addresses the off-site concepts in the construction SC (Mostafa et al. 2014) demonstrating the transfer of activities from site to SC (Vrijhoef \& Koskela, 2000). The OSM approach creates a space for application of lean supply with similarities driven by manufacturing to construction but demands more integrated processes (Fearne $\&$ Fowler, 2006). Adoption of lean production principles also improves the performance of SCM (Flores et al. 2009), but it is more challenging in the context of the construction industry (Höök \& Stehn, 2008). A triangulation improvement strategy based on OSM, SCM and lean for house building projects is gaining attention by construction community (Pero et al. 2015), however, focus on CFS OSM technology is still limited (Boyd et al. 2012).

To evaluate the OSM SCM and lean, VSM is a potential lean thinking tool for performance measurement and mapping. A value stream comprised of all the activities which are value-adding, non-value adding or necessary but not always adding value (Rother \& Shook, 2003). VSM helps to identify the flow, value, and perfection (Womack \& Jones, 2010). In empirical studies (Arbulu et al. 2003; Fontanini \& Picchi, 2004), the current state maps processes and agents, and identifies wastes (non-value adding activities) and relevant problems in processes and interfaces, focusing on a single product SC. For the future, solutions and strategies are proposed that can improve overall performance.

\section{RESEARCH METHOD}

A case study approach is adopted (Yin, 2013) that focusses on the OSM SC of six CFS houses of different sizes, but follows the same SC. The steps followed in this study follow the guidelines from valid sources (Dolcemascolo, 2006; Rother \& Shook, 2003; Womack \& Jones, 2010), to apply VSM. Most critical step is selection of product family i.e. structural framing of CFS houses. Data collection was done through project and company documentation. Also, interviews with five employees (with designations as commercial manager, business development manager, sales manager, design manager, factory manager and foreman) involved in the marketing, design, and manufacturing, having experience from 5 to 15 years in the CFS housing industry.

The lead time was considered as a key performance indicator (Yu et al. 2009) for single components (i.e. CFS framing) in the house building SC. Lead time helps to understand the complete SC from order to delivery of a particular project (Arbulu et al. 2003), and comprises factors such as process time and queue time, refer to Table 1.

Units of analysis for processes in design and manufacturing were area/time and length/time respectively. Initially, ERP documentation for process flow was reviewed. Interviews were conducted with key personnel of the company. The current state map shows key processes, interfaces; stakeholders (or agents) were identified. The time for each process and queue time at the interface were also determined. Key observations developed on reasons for non-value adding process time and queue or wait time in the value stream which leads the investigation to some wastes causing long lead time. A future state map was proposed addressing the peculiarities of identified wastes which has the potential to improve the OSM SC with reduced lead time, which also impacts the overall lead time of the house building stock. 
Table 1: Process Indicator

\begin{tabular}{cccc}
\hline Name & Acronym & Unit & Description \\
\hline Process time & PT & Hours & Value adding time \\
Queue time & QT & Hours & Non-value adding time \\
Lead time & LT & Days & Time from order to delivery \\
\hline
\end{tabular}

\section{CASE STUDY DEVELOPMENT}

The selection of product family has described i.e. CFS structural framing for housing. The selection of the product is a critical step towards VSM in the context of construction SCM, as performed in empirical studies (Arbulu et al. 2003; Fontanini \& Picchi, 2004). Selection of a critical product/material of building is necessary which has a pivotal influence on the performance of the overall process and SCM (Rosenbaum et al. 2013; Yu et al. 2009).

In New Zealand, the construction industry has an overall contribution of $52 \%$ in gross fixed price formation; 26\% covers housing (MBIE, 2013). Detached houses with one or two floors are common, covering $75 \%$ building consents per year (MacPherson, 2016). The average size of a dwelling in NZ is 149 square meters (QV, 2011). Preliminary data of six houses has been considered with dwelling sizes ranging from $88 \mathrm{~m} 2$ to $200 \mathrm{~m} 2$, and an average size of $139 \mathrm{~m} 2$.

For VSM, there is a need to select a product or product family following criteria based on high volume by revenue, high volume by units produced, high defect rates, highest customer return rate, and visit the most processes (Dolcemascolo, 2006). A particular house is made up of several building components but structural framing is more critical because more than $90 \%$ of building components (services, cladding, and all finishing) in house building follows the structural framing, so that, it can affect the construction of house building in term of time, quality and cost.

In New Zealand, structural framing is manufactured by different OSM technologies such as timber and CFS. According to National Association of Steel-framed Housing (NASH), the market share of CFS housing is increasing and expected to achieve $10 \%$ in coming years (Davies, 2009). CFS is very well utilized in OSM which creates promising affordable technology but with low uptake by housing industry stakeholder, which is a common scenario in the construction industry for new construction technologies (Donyavi et al., 2009). CFS framing (i.e. roof trusses and wall panels) are one of the most common approaches in New Zealand (PrefabNZ, 2016). This study focused on the design and manufacturing of CFS framing for housing as it has the potential to create value in SC by reducing the overall lead time of housing. The firm selected for this research is a leading in CFS OSM technology covering both designing and manufacturing domains. The company has a well-established business setup in New Zealand (around 50 employees with an estimated 5 million dollars of revenue per year) and clients around the globe using their technologies for design and manufacturing.

\section{VALUE STREAM ANALYSIS}

A highly or macro level value stream map was developed (Figure 1), identifying the SC configuration with key firms (agents), processes and workflow. Linkage with both end 
Value Stream Mapping - A Case Study of Cold-Formed Steel House Framing for Offsite Manufacturing Supply Chain

arrows shows two-way communication. In this preliminary research, only VSM for one design and manufacturing firm was developed focusing only on the analysis of the current and future state.

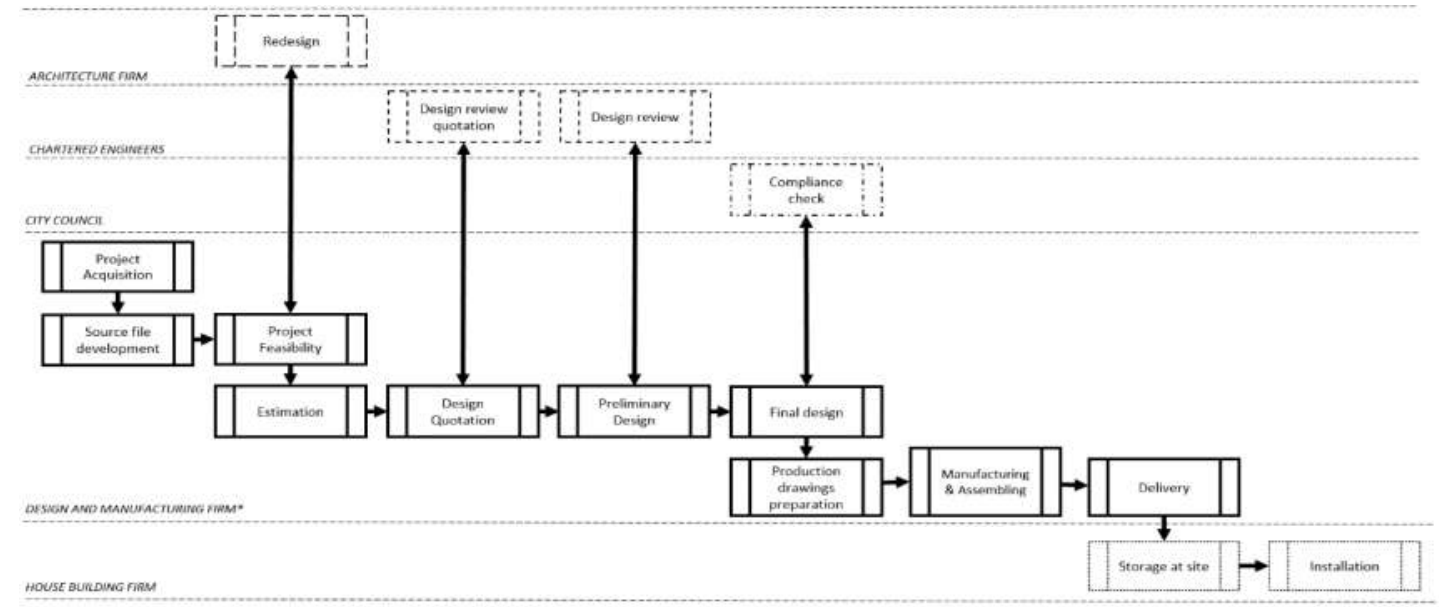

Figure 1: Value Stream Macro Mapping - Current state

For simplification, time of external processes is taken as queue time for internal processes as the scope is limited to design and manufacturing firm. For example, the design of structural framing is not finalized until approval from the council is obtained, with respect to code compliance; for the company, it is a non-value adding step and causes queue time. There are ten processes involved in the value stream of CFS framing from order to delivery. Each box represents a process and is considered to add value in the value stream; triangles represent the wait/queue time.

\subsection{Value stream map - Current state}

Figure 2 shows the VSM of the SC of CFS structural framing in the context of the company with ten processes.

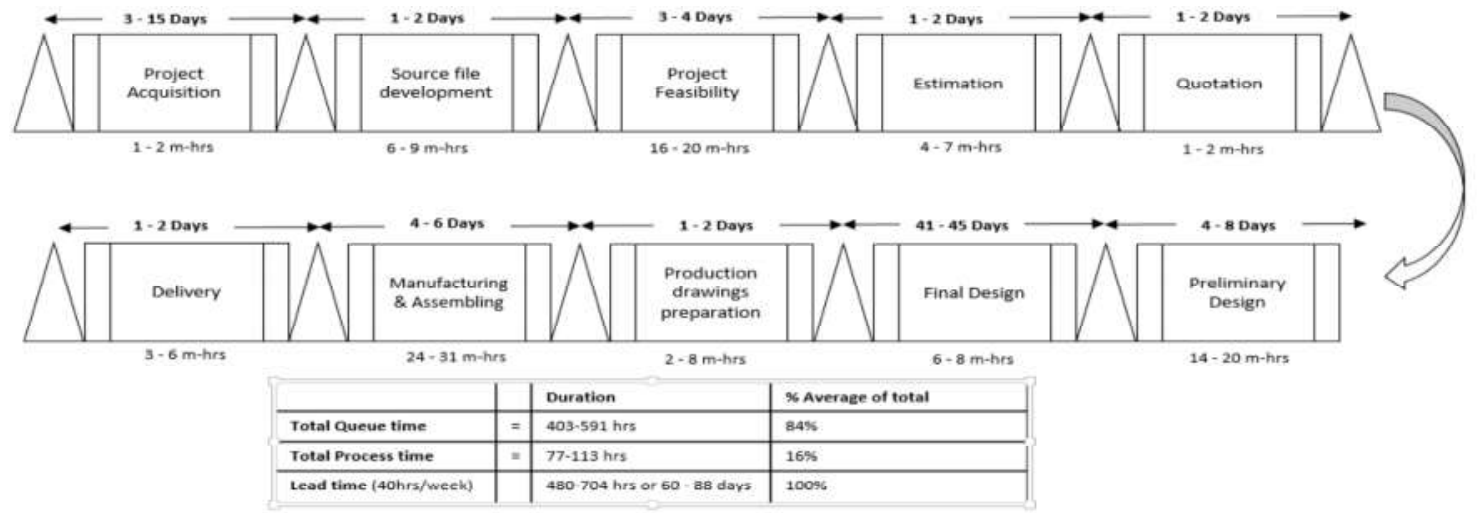

Figure 2: Value Stream Mapping - Current state

The total time taken by each process ranges from between 77 and 113 hours (10 and 14 days) i.e. 16\% Queue times ranges between 403 and 591 hours (50 and 74 days) i.e. 84\% of the whole system time. The lead time of CFS framing from order to delivery (i.e. process times and queue time) is 60 to 88 days, assuming eight man hours per day. Information flow (i.e., design information) is visible in the first eight steps in the SC, but the material flow is seen only in the last two processes. Communication within design and manufacturing follows ERP system of the firm. Table 02 shows wastes, mainly drive 
through site observations, identify a number of possible wastes defined by Locher (2011), see Table 02;

Table 02: Common waste in OSM supply chain

\begin{tabular}{|c|c|}
\hline Waste & Description \\
\hline $\begin{array}{l}\text { Over } \\
\text { production }\end{array}$ & $\begin{array}{l}\text { CFS OSM technology is comparatively new, so clients take on average two weeks to place the } \\
\text { order. The client needs } 1-2 \text { visits to the factory to understand this technology. Energy spent on this } \\
\text { process is considered to be overproduction because it is not adding value. }\end{array}$ \\
\hline Transportation & $\begin{array}{l}\text { The transportation waste is observed in information flow when the client provides hard copy, and } \\
\text { furthermore, the process of code check is done manually by the council. The effort is needed to } \\
\text { manoeuvre the framing panel for congested space in a factory, or the site is not ready for } \\
\text { installation. }\end{array}$ \\
\hline $\begin{array}{l}\text { Inappropriate } \\
\text { processing }\end{array}$ & $\begin{array}{l}\text { The architectural drawing is developed in CAD as a source file, which takes } 1-2 \text { days depending } \\
\text { on the complexity of the design. Later on, in project feasibility stage, the constructability of design } \\
\text { is checked which takes } 3-4 \text { days. For example, there is a limitation of floors, span length, and } \\
\text { openings' areas. Both of these processes are inappropriate which are non-value adding to the SC. }\end{array}$ \\
\hline Defects & $\begin{array}{l}\text { Defects are associated with the waste of time and resources, generated from wrong design } \\
\text { (compliance issues); errors in the production file; manufacturing machine malfunction; a poor } \\
\text { quality control system; unskilled operators, assemblers, and installers. }\end{array}$ \\
\hline $\begin{array}{l}\text { Unnecessary } \\
\text { inventory }\end{array}$ & $\begin{array}{l}\text { OSM needs economies of scale (mass production) but the production depends on the capacity of } \\
\text { industrialized organization and projects at hand. Raw material is normally stocked for 4-6 months, } \\
\text { which depends on the availability in both local and overseas markets. Current research shows that } \\
\text { on average two house building framings per month are constructed. Low demand of framing and } \\
\text { variation in profiles leads to unnecessary inventory. }\end{array}$ \\
\hline Waiting & $\begin{array}{l}\text { Waiting times is the key waste in the SC. The client takes time in making decisions at different } \\
\text { stages in SC, such as providing architectural drawings, resolving constructability issues with } \\
\text { architect, approval for manufacturing. The quotations generated are normally valid for one month. } \\
\text { The council takes around 1-2 months to approve the design for housing projects. }\end{array}$ \\
\hline $\begin{array}{l}\text { Unnecessary } \\
\text { movement }\end{array}$ & $\begin{array}{l}\text { Poor factory layout causes unnecessary movement of workers during setting up, manufacturing, } \\
\text { assembling and stacking which impact the productivity. }\end{array}$ \\
\hline $\begin{array}{l}\text { Underutilized } \\
\text { people }\end{array}$ & $\begin{array}{l}\text { This refers to the potential of employees is not fully utilized. Third party review is not needed if } \\
\text { the design engineer at the organization is a chartered engineer, which will reduce time in } \\
\text { quotation and preliminary design processes. There is a need of four workers during manufacturing } \\
\text { and assembling process. }\end{array}$ \\
\hline
\end{tabular}

\subsection{Value stream map - Future state}

Womack and Jones (2010) proposed that a future state could demonstrate waste elimination with the application of lean principles. The improvement should take place in quality, productivity and lead times (Rother \& Shook, 2003). This proposed research aims to reduce the lead time of CFS framing for housing projects (see Figure 3). The future state proposes two processes to be eliminated i.e. source file development and project feasibility. Architectural drawing should be provided by the client in CAD format preferably in IFC format so that it can be opened to any structural design drawing format. The architect should consider the potential and limitation CFS OSM technology while designing the house for elimination of project feasibility process. The time of four processes (estimation, quotation, production drawing preparation, and delivery) cannot be reduced significantly because of the requirements of the processes. Use of building information modelling (BIM) technologies improves visualization, estimation and drawing generation. The time for four processes also queue time can be reduced significantly (project acquisition through selection of bespoke design; preliminary design by avoiding third party involvement, final design by efficiently address the compliance issues, manufacturing and assembling by enhancing productivity of workers). 
Value Stream Mapping - A Case Study of Cold-Formed Steel House Framing for Offsite Manufacturing Supply Chain

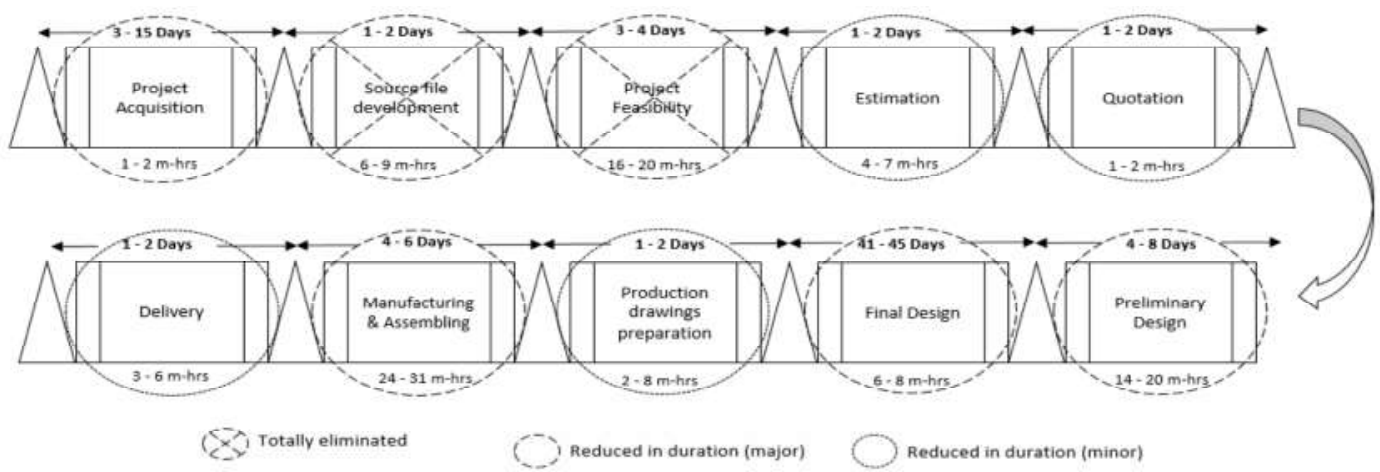

Figure 3: Value Stream Mapping - Future state

Industrialized firms should take measures to housing market the potential and benefits of OSM, which helps to increase the adoption and increase the trust level of client on OSM. Although, there is less provision for design modifications (i.e. flexibility), which encourages the standardization, but limits the innovation as the bespoke design modification takes less time. Code compliance can be performed through BIM, which can help to reduce checking time at the council. Productivity during manufacturing and assembling of CFS framing can be increased through simulation by using BIM, as the scenario can be different in terms of factory layout and worker behaviour. It is needed to explore more BIM potentials integrated with lean construction to efficiently manage CFS OSM SC through solving problems. It is estimated that by using the propose strategies mentioned above, the lead time can be reduced to 10-15 days if the queue time and process time is reduced or eliminated, which helps in enhancing supply of housing stock.

\section{CONCLUSION}

This research has presented a preliminary diagnosis of OSM SC in for CFS structural framing of housing projects. Understanding the SC helps members for decision making regarding adoption of OSM technologies which leads to construction innovation and enhancing business portfolio. Addressing the inefficiencies in context of CFS OSM SCM enhance the supply of house building and increase affordability along with high quality. This study focused on private housing, and SC configuration is different for social or relief housing constructed through OSM. This study canvas the prevailing practices and problems in CFS OSM SCM which helps in enhancing the adoption of OSM technologies in construction. Limitation of performance measurement frameworks (such as balanced scorecard and SCOR) for SCM of house building projects highlights the need of dynamic framework based on well-developed performance indicators. This study shows the potential of VSM as a performance measurement and lean improvement tool for the OSM SC for CFS. The waste in different OSM technologies SC also varies regarding nature and impact. This study reported eight common wastes in value stream of CFS OSM SC which will be further investigated to understand the impact on overall performance. The future stage suggests that the lead time of SC can be reduced if the recommended strategies are implemented. This study provides grounds to explore the lean approach for improvement in the SC of housing with BIM, keeping the OSM technology perspective, which is changing the dynamics of the construction industry on a global scale. A further research focuses on the development of a BIM-lean integrated theoretical and methodological framework to improve OSM SCM in CFS housing industry. 


\section{REFERENCES}

Arbulu, R. J., Tommelein, I. D., Walsh, K. D., \& Hershauer, J. C. (2003). Value stream analysis of a re-engineered construction supply chain. Building Research and Information, 31(2), 161-171. 10.1080/09613210301993

Bassett, M., \& Malpass, L. (2015). Priced Out: How New Zealand Lost its Housing Affordability Wellington, New Zealand The New Zealand initiative

Boyd, N., Khalfan, M. M., \& Maqsood, T. (2012). Off-site construction of apartment buildings. Journal of Architectural Engineering, 19(1), 51-57.

Dolcemascolo, D. (2006). Improving the Extended Value Stream: Lean for the Entire Supply Chain. New York, USA: Taylor \& Francis.

Edum-Fotwe, F. T., Thorpe, A., \& McCaffer, R. (2001). Information procurement practices of key actors in construction supply chains. European Journal of Purchasing \& Supply Management, 7(3), 155-164. http://dx.doi.org/10.1016/S0969-7012(00)00024-1

Fearne, A., \& Fowler, N. (2006). Efficiency versus effectiveness in construction supply chains: the dangers of "lean" thinking in isolation. Supply chain management: An international journal, 11(4), 283-287.

Flores, M., Mendoza, A., Lavin, V., \& Flores, B. (2009). Developing a Taxonomy and Model to Transfer and Assess Best Practices for Supply Chain Management Leveraging Knowledge for Innovation in Collaborative Networks (pp. 109-116): Springer.

Fontanini, P. S., \& Picchi, F. A. (2004, 2004). Value stream macro mapping-a case study of aluminum windows for construction supply chain. Paper presented at the Twelfth Conference of the International Group for Lean Construction (IGLC 12), Helsingør, Denmark.

Gann, D. M. (1996). Construction as a manufacturing process? Similarities and differences between industrialized housing and car production in Japan. Construction Management \& Economics, 14(5), 437-450.

Goulding, J. S., Pour-Rahimian, F., Arif, M., \& Sharp, M. (2015). New offsite production and business models in construction: priorities for the future research agenda. Architectural Engineering and Design Management, 11(3), 163-184.

Höök, M., \& Stehn, L. (2008). Applicability of lean principles and practices in industrialized housing production. Construction Management and Economics, 26(10), 1091-1100.

Locher, D. A. (2011). Value stream mapping for lean development: A how-to guide for streamlining time to market: CRC Press.

London, K., \& Siva, J. (2011). Integrated housing supply chain model for innovation: Narrative analysis towards developing pathways methodology. Paper presented at the Management and Innovation for a Sustainable Built Environment Conference.

MacPherson, L. (2016). Building Conscents Issues: January 2016. Wellington Statistics New Zealand. Retrieved from http://www.stats.govt.nz/browse_for_stats/industry_sectors/Construction/BuildingCo nsentsIssued_HOTPJan16.aspx

MBIE. (2013). CONSTRUCTION. New Zealand: Ministry of Business, Innovation and Employment.

MHC. (2011). Prefabrication and Modularization: Inreasing Productivity in the Construction Industry. Bedford, USA: Mc-Graw Hill Construction, Research \& Analytics.

Mostafa, S., Chileshe, N., \& Zuo, J. (2014, 25-27 Jun 2014). Enhancing Australian Housing Affordabillity: Off-site Manufacturing Supply Chain Strategies. Paper presented at the 
Value Stream Mapping - A Case Study of Cold-Formed Steel House Framing for Offsite Manufacturing

Supply Chain

22nd Annual Conference of the International Group for Lean Construction, Oslo, Norway

Pan, W., Gibb, A. G. F., \& Dainty, A. R. J. (2012). Strategies for Integrating the Use of OffSite Production Technologies in House Building. Journal of Construction Engineering and Management, 138(11), 1331-1340. 10.1061/(asce)co.1943-7862.0000544

Pero, M., Stößlein, M., \& Cigolini, R. (2015). Linking product modularity to supply chain integration in the construction and shipbuilding industries. International Journal of Production Economics, 170, Part B, 602-615. http://dx.doi.org/10.1016/j.ijpe.2015.05.011

PrefabNZ. (2016). 5 year impact report (2010-2015) - Levers for Prefab Action Plan. Wellington, New Zealand: PrefabNZ.Retrieved from http://www.prefabnz.com/html/blob.php/PrefabNZ.5yrImpactReport.pdf?attach=false \&documentCode $=9911$

QV. (2011, April 12, 2011). Average House Size by Area. Retrieved September 01, 2016, from https://www.qv.co.nz/resources/news/article?blogId=61

Rosenbaum, S., Toledo, M., \& González, V. (2013). Improving Environmental and Production Performance in Construction Projects Using Value-Stream Mapping: Case Study. Journal of Construction Engineering and Management, 140(2), 04013045. 10.1061/(ASCE)CO.1943-7862.0000793

Rother, M., \& Shook, J. (2003). Learning to see - Value Stream Mapping to Create Value and Eliminate Muda. Cambridge, MA USA: Lean Enterprise Institute.

Scofield, R., Wilkinson, S., Potangaroa, R., \& Rotimi, F. (2009. Driving Innovative Offsite Construction Techniques in New Zealand. Global Innovation in Construction Conference, Holywell Park, Loughborough University, UK

Vrijhoef, R., \& Koskela, L. (2000). The four roles of supply chain management in construction. European Journal of Purchasing \& Supply Management, 6(3-4), 169-178. http://dx.doi.org/10.1016/S0969-7012(00)00013-7

Womack, J. P., \& Jones, D. T. (2010). Lean Thinking: Banish Waste and Create Wealth in Your Corporation: Free Press.

Yin, R. K. (2013). Case study research: Design and methods: Sage publications.

Yu, H., Tweed, T., Al-Hussein, M., \& Nasseri, R. (2009). Development of Lean Model for House Construction Using Value Stream Mapping. Journal of Construction Engineering and Management, 135(8), 782-790. 10.1061/(ASCE)07339364(2009)135:8(782) 